\title{
Book Review Bioethics and Population
}

Book Review of

Bioethics and Population: The Choice of Life, by Michel Schooyans; translated by John H. Miller, (1997), xiv +112p.

'Chesterton once said, "If a man does not talk to himself it is because he is not worth talking to." Read this book and you will have much worth talking about. It is a cornucopia of insights important to anyone devoted to "life issues."

Take 146 pro-choice and anti-life loaded and leading questions; group them into 16 broad categories called "chapters" listing all in a table of contents; then answer all the questions in 100 pages of text; and you get this book.

It was at question 1 of the table of contents tnt I started talking to myself and did so for 20 minutes until I completed the 8-page table of contents. Of course, I was not only talking to myself but kidding myself, because I already was acquainted with the author of this book from his previous masterpiece, POWER OVER LIFE. So, charged with enthusiasm, I stopped talking to myself and started reading the text. Admiration for the author expanded.

The book answers all the tough questions pointedly, concisely and understandably. Pro-abortionists will hate this book to censorship. Whatever they say will be rebutted on another page. Amazing! Properly referenced, it is a debater's joy. Having been in the abortion war since 1969, I sense the value of this book. One can look up a topic, read the text wait for the pro-abort's response, then look that up and read the text once again. Schooyans gives much worth talking about and not only to oneself. Socrates and St. Thomas are alive and well.

It is difficult to give a flavor of the book because it stands alone. A brief effort

"Pleasure" is identified as the contemporary "superiority of Nazis," wherein anything not pleasurable can be done away with. "Final solutions" embrace us now for whatever or whoever reduces pleasure. Recognized is the three-way equivalence of disposability, the liberal ideal and Nazism for the common people. Nazism proved people could be duped into doing anything and abortion confirms it. Only today, it is Nazism with slick civility (Yeah, yell "civility" as one is thrown into a tree branch grinder - the perfect analogy to being aborted). Abortion is the Catholic Rejection, the Protestant Revelation, and the Jewish Revenge. Nazism has triumphed, but the packaging is merely different, which enables the legitimatization of Nazi discrimination procedures made palatable because evil laws are no longer resisted even though Nuremberg rejected "following orders" as an excuse. And woe to those who do not "follow orders" to abort One quickly realizes that with the attitudes of today's pro-aborts, Naziism has won and not so secretly.

Schooyans points out that this is accomplished by "the arithmetic of pleasure" making a "juridical space for crime" resulting in a "moral norm of convenience" - three haunting phrases rendering Schooyans unforgettable. The result is what is obvious to everyone who stops to think about it: a massive lack of respect for doctors, judges, medicine and the law. Do not

\author{
Perspective \\ Special Issue - 2015 \\ Dr. Samuel A Nigro M.D* \\ Retired, Assistant Clinical Professor Psychiatry, Case Western \\ Reserve University School of Medicine, USA \\ *Corresponding author: Dr. Samuel A Nigro M.D, Retired, \\ Assistant Clinical Professor Psychiatry, Case Western Reserve \\ University School of Medicine, 2517 Guilford Road, Cleveland \\ Heights, Ohio 44118, USA, Tel: 216 932-0575; Email: sam@ \\ docnigro.com
}

Received: August 19, 2015 | Published: October 06, 2015

deny that. Think about it. Schooyans makes clear the impact of all these anti-life policies: Nations are being sterilized; sophistry has triumphed; the social morality is "do not disturb me," and the impact of childlessness on the aged results in nothing but the ghoulish perspective of street urchins grown old into walking cadavers. And poor Europe - where programs for the poor have backfired into pogroms for themselves. The demographic collapse of Europe ensures an unstated American World Empire of "billionaires of the world unite!" hidden in abusive power intrinsic to the United Nations (based in and therefore controlled by the United States) as the UN becomes a supernational authority with a world (read "plutocrat") government-for-profit.

Schooyans offers a profound analysis of the proverbial "big picture" by a prescience which is not for the squeamish.

Schooyans asks: "Is poverty reduced by the reduction of births?" Think about that! I hate pointing out this similarity, but Michel Schooyans is our Paul Ehrlich (The Population Bomb) except Schooyans is not an environmental wacko ecoterrorist and most assuredy more correct than Ehrlich ever was.

One cannot overlook his startling insight that the promotion of abortion coincides completely with society's mutual and reciprocating alienation from the offspring allowed to live - an observation so true from our experience that it is chilling. Our children hate us and our society, and society hates them regardless of mouthed platitudes to the contrary. Schooyans identifies this and tells why.

One learns the origins of those terrible feelings of hate and contempt. In spite of conscious determination to the contrary, for judges and doctors and the source of that massive disgust with the law and the reluctant disappointment for the corpse of what was the profession, medicine.

One sees clearly what society has become: a victimhood contest where victims must be certified by those who cannot say "no" to evil; a society with a thunderous gnawing hunger and thirst for the transcendentals; a society which tolerates psychopaths as leaders because the press and media are psychopathic. In sum, man's worst enemy is the venomous superstitious terrorism that 
we can do violence to nature's rules without consequences.

Indeed, the only thing missing from this book is the demonic anti-life emphasis of the Evil Empire of the Press and Media, which needs to trump up a spurious racism as reason for burning Christian churches to camouflage the gross anti-Christianity of Hollywood and Disney. I hope Schooyans will soon address the malignant impact of the press and media consistent with my booklet Satan Turned Into an Angel of Light.
This is the new "Right to Life Handbook." It offers a scholarly process which recognizes that evil ideas cannot be treated nicely.

"It is books like this that maintain the soul of mankind and the planet. To paraphrase GM Chesterton: The plain facts of the planet are against what we are doing to ourselves through antilife actions regardless of rationalizations. 